\title{
EXPERIMENTAL PAPER
}

\section{Functional traits of selected clones of southern sweet-grass (Hierochloë australis /Schrad./ Roem. \& Schult.)}

\author{
KATARZYNA BĄCZEK*, MIROSŁAW ANGIELCZYK, JAROSŁAW L. PRZYBYŁ, MARCIN \\ EJDYS, ANNA GESZPRYCH, ZENON WĘGLARZ
}

\section{Laboratory of New Herbal Products}

Department of Vegetable and Medicinal Plants

Warsaw University of Life Sciences - SGGW

Nowoursynowska 166

02-787 Warsaw, Poland

*corresponding author: e-mail: katarzyna_baczek@sggw.pl, phone: +48 22 5932258, fax: +48 225932232

\section{Sum m a r y}

Southern sweet-grass (Hierochloë australis /Schrad./ Roem. \& Schult., Poaceae), commonly known as a bison grass, is a perennial tuft grass rarely occurring in mixed forests in Eastern and Northern Europe. The raw material collected from this plant are leaves rich in coumarin compounds (especially coumarin) responsible for sweet, specific aroma of these organs. In Poland, southern sweet-grass leaves are used mainly for alcohol products aromatisation. Growing demand for the raw material results in uncontrolled and excessive collecting of this plant. The best way to solve this problem is to introduce this plant into cultivation. Since southern sweet-grass is allogamous and heterozigotic, strong intraspecific variability of the species is observed.

Fourteen clones of selected individuals from one population of southern sweet-grass naturally occurring in East Poland were compared in respect of morphological traits as well as accumulation of biologically active compounds. The clones differed significantly in the weight of leaves (3.76-22.59 g of air-dry weight per plant). The total coumarin content (determined by a spectrophotometric method) in this raw material for investigated clones ranged from 1.49 to $1.94 \%$, flavonoids - from 0.25 to $0.55 \%$, and phenolic acids - from 0.20 to $0.42 \%$. Three coumarin compounds were identified by HPLC, namely coumarin, 3,4-dihydrocoumarin, and o-coumaric acid. The content of coumarin ranged from 84.00 to 310.85, 3,4-dihydrocoumarin: from 17.80 to 168.45 , and o-coumaric acid: from 37.50 to $70.00 \mathrm{mg} \cdot 100 \mathrm{~g}^{-1}$ dry matter.

Key words: plant variability, morphological traits, coumarins, flavonoids, phenolic acids 


\section{INTRODUCTION}

Southern sweet-grass (Hierochloë australis /Schrad./ Roem. \& Schult.) belonging to the family Poaceae is a perennial tuft grass growing wild in mixed forest in Central Europe (mostly in Poland, Belarus, and Finland). The populations of this species are scattered. A decrease in the number of natural sites and in the numerical force of populations has been observed. In Poland it has a status of the species vulnerable to extinction [1].

Leaves of southern sweet-grass are rich in coumarin and related compounds. These compounds are present both in the leaf tissue and in the white powdery bloom on the leaf surface [2]. The presence of coumarin results in the specific aroma of dried leaves. Leaf extracts are mainly used for aromatization of alcoholic drinks and cigarettes. Some medicinal applications of this raw material are also known. Coumarin is a mild antispasmodic and sedative. Its anticarcinogenic activity has been reported but also the risk of hepatotoxic and carcinogenic effects at high doses [3-5].

Since 1983, southern sweet-grass is partially protected in Poland. However, wild growing plants are still collected. The reduction of collecting from the wild may be achieved by introduction of this plant into cultivation. Taking into consideration the demand of the industry for the uniform raw material, it is advisable to cultivate clones of selected individuals distinguished by desirable functional traits.

The aim of this study was to compare selected clones of southern sweet-grass both in respect of developmental and chemical traits.

\section{MATERIALS AND METHODS}

\section{Plant material}

The object of the study were 14 clones of southern sweet-grass obtained by dividing selected plants (individuals) from the natural site in Podlasie area (N $52^{\circ}$ 37.944' E $22^{\circ} 45.718^{\prime}$, fig. 1). The criteria for the selection of donor population was a relatively big area of natural site $\left(200 \mathrm{~m}^{2}\right)$, relatively great number of individuals allowing for sampling without threatening the population survival, and high coumarin content in the leaves of these plants, which has been stated in the previous studies (unpublished data). Fourteen individuals that differed in respect of morphological traits (length and width of leaves, and intensity of leaf coating with the powdery bloom) were selected for vegetative propagation (cloning). They were dug out in April 2010 and divided into five-blade cuttings, which were planted in the greenhouse in multi-cell trays filled with the mix of peat and sand (1:1) of $\mathrm{pH}$ 6.0. After three months the rooted cuttings were planted in the experimental field of the Department of Vegetable and Medicinal Plants in Warsaw, at the density of $30 \times 50 \mathrm{~cm}$. Each clone was represented by 30 plants obtained from the same mother plant. 


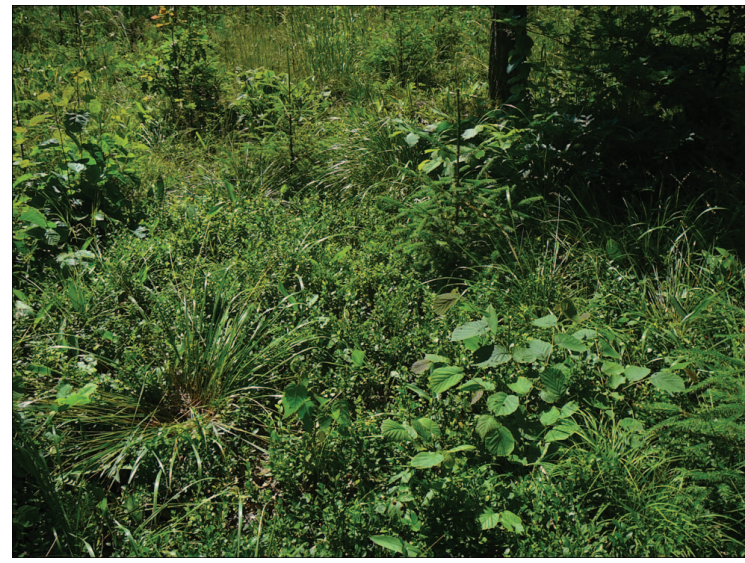

Figure 1.

Natural site of southern sweet-grass mother plants of investigated clones
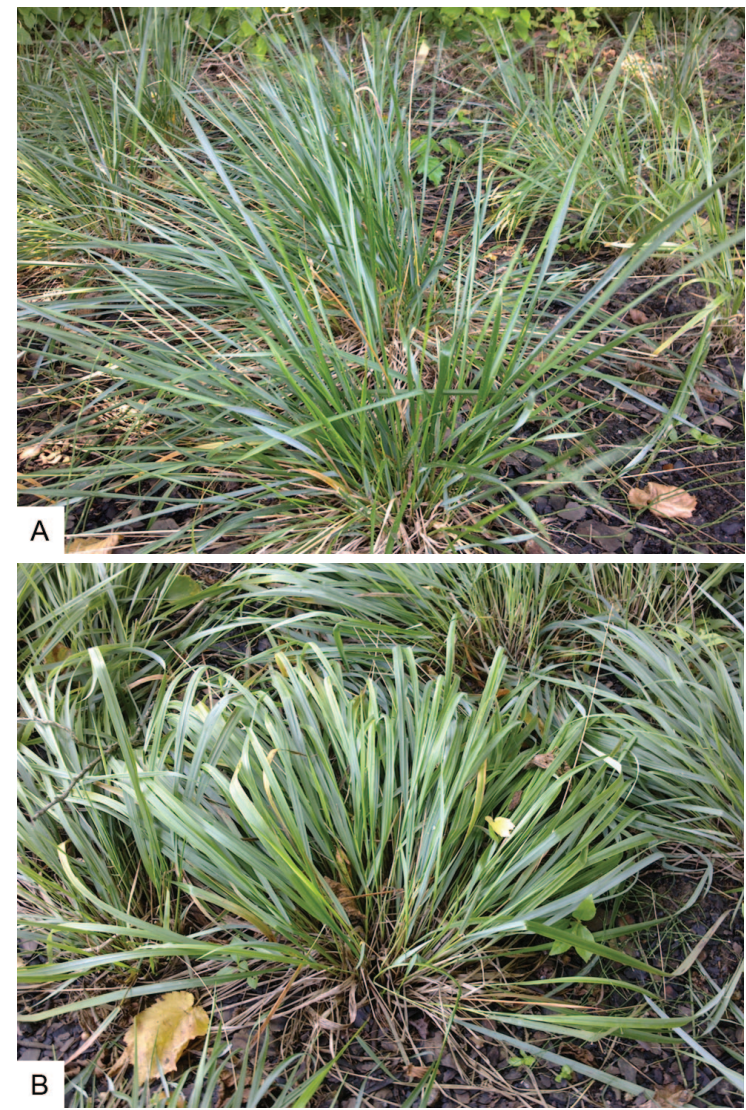

Figure 2.

Example of morphological variability between investigated clones of southern sweet-grass: A - clone No. 8, B - clone No. 12 


\section{Morphological characteristics}

The morphological traits of ten randomly selected plants representing each of the investigated clones were evaluated in the second year of vegetation (August 2012), at the stage of vegetative growth following flowering and seed setting. The determined parameters included the number of leaves per plant and leaf size (length and width). For the evaluation of leaf size thirty leaves of each plant were measured. The weight of leaves per plant was determined directly after harvest (fresh weight) and after drying at $35^{\circ} \mathrm{C}$ (air-dry weight).

\section{Determination of the total contents of coumarins, flavonoids, and phenolic acids}

Total content of coumarins was determined by spectrophotometric method described by Wierzchowska-Renke and Stecka [6].

Total content of flavonoids (expressed as quercetin equivalents, \%) was determined spectrophotometrically, according to Polish Pharmacopoeia [7].

Total content of phenolic acids (expressed as caffeic acid equivalents, \%) was also determined spectrophotometrically, according to the method described in the Polish Pharmacopoeia [7] for the herb of artichoke.

\section{HPLC analysis of leaf extracts}

Extracts for chromatographic analyses were obtained by exhaustive extraction of the grounded leaf sample $(1.0 \mathrm{~g})$ with $100 \mathrm{ml}$ of methanol in B-811 Extraction System (Büchi). After evaporation of solvent, the residue was dissolved in $10 \mathrm{ml}$ of methanol, filtered through a Supelco IsoDisc Cellulose $25 \mathrm{~mm} \times 0.2 \mu \mathrm{m}$ filter, and subjected to HPLC.

The analysis was carried out using the Shimadzu chromatograph with SPDM10A VP DAD detector equipped with Kinetex $2.6 \mu \mathrm{m} \mathrm{C18} \mathrm{100A} 100 \mathrm{~mm} \times$ $4.6 \mathrm{~mm}$ column (Phenomenex). The gradient of water acidified with $0.1 \%$ phosphoric acid (A) and acetonitrile (ACN) acidified with $0.1 \%$ phosphoric acid (B) was used, at the flow rate of $1.0 \mathrm{ml} \cdot \mathrm{min}^{-1}$. Time of analysis was $10 \mathrm{~min}$., recorded wave range: $190-900 \mathrm{~nm}$, detection wavelength: $273 \mathrm{~nm}$ (2,3-dihydrocoumarin) and $276 \mathrm{~nm}$ (coumarin and o-coumaric acid). Peaks were identified by comparison of retention time and spectral data with the adequate parameters of standards (Chromadex). Quantification was based on the peak area. The content of the determined compounds was calculated in $\mathrm{mg} \cdot 100 \mathrm{~g}^{-1}$ dry matter.

All the analyses were made in three replications. 


\section{Statistical analysis}

The results were subjected to the one-way analysis of variance and Tukey's test at $\alpha=0.05$. The coefficient of variation (CV) for the morphological traits and for the content of determined compounds was calculated.

\section{RESULTS}

The investigated clones differed in morphological traits as well as in accumulation of coumarin and phenolic compounds. From among the morphological traits, the highest variability was observed in the weight of leaves per plant. Fresh weight of leaves ranged from 11.33 to $70.00 \mathrm{~g} \cdot$ plant $^{-1}$, and air-dry weight from 3.76 to $22.59 \mathrm{~g} \cdot$ plant $^{-1}$. High diversity concerned also the number of leaves per plant (94-298), whereas leaf size was less diversified: leaf length ranged from 28.03 to $43.73 \mathrm{~cm}$, and leaf width from 5.97 to $9.60 \mathrm{~mm}$. The biggest leaves and the highest weight of leaves were characteristic for the clone no. 12 (tab. 1, fig. 2).

Table 1 .

Morphological traits of the investigated clones of southern sweet-grass

\begin{tabular}{|c|c|c|c|c|c|c|c|c|c|c|}
\hline \multirow{2}{*}{$\begin{array}{c}\text { Clone } \\
\text { No. }\end{array}$} & \multicolumn{2}{|c|}{$\begin{array}{c}\text { Number } \\
\text { of leaves per plant }\end{array}$} & \multicolumn{2}{|c|}{ Leaf length [cm] } & \multicolumn{2}{|c|}{ Leaf width [mm] } & \multicolumn{2}{|c|}{$\begin{array}{c}\text { Fresh weight } \\
\text { of leaves } \\
{\left[\mathrm{g} \cdot \text { plant }^{-1}\right]}\end{array}$} & \multicolumn{2}{|c|}{$\begin{array}{c}\text { Air-dry weight } \\
\text { of leaves } \\
{\left[\mathrm{g} \cdot \text { plant }^{-1}\right]}\end{array}$} \\
\hline & 111.0 & b & 36.10 & bc & 8.43 & $a b c$ & 23.33 & $\mathrm{~b}$ & 8.22 & $\mathrm{ab}$ \\
\hline 2 & 143.0 & $\mathrm{ab}$ & 37.97 & $\mathrm{ab}$ & 8.80 & $a b$ & 30.00 & $\mathrm{ab}$ & 10.22 & $\mathrm{ab}$ \\
\hline 3 & 191.7 & $\mathrm{ab}$ & 32.00 & $\mathrm{~cd}$ & 7.30 & bcde & 24.00 & $\mathrm{~b}$ & 7.85 & $\mathrm{ab}$ \\
\hline 4 & 201.7 & $\mathrm{ab}$ & 30.90 & $\mathrm{~cd}$ & 7.27 & bcde & 27.33 & $\mathrm{~b}$ & 7.98 & $\mathrm{ab}$ \\
\hline 5 & 94.0 & b & 28.03 & d & 6.00 & e & 11.33 & $\mathrm{~b}$ & 3.76 & b \\
\hline 6 & 187.0 & $\mathrm{ab}$ & 30.90 & $\mathrm{~cd}$ & 6.90 & cde & 24.67 & $\mathrm{~b}$ & 8.45 & $\mathrm{ab}$ \\
\hline 7 & 204.7 & $\mathrm{ab}$ & 29.73 & d & 6.27 & de & 23.33 & $\mathrm{~b}$ & 6.89 & b \\
\hline 8 & 156.0 & $\mathrm{ab}$ & 31.77 & $\mathrm{~cd}$ & 5.97 & e & 21.67 & $\mathrm{~b}$ & 6.56 & $b$ \\
\hline 9 & 130.7 & $\mathrm{ab}$ & 29.27 & d & 6.23 & de & 16.00 & $\mathrm{~b}$ & 5.05 & $\mathrm{~b}$ \\
\hline 10 & 169.7 & $\mathrm{ab}$ & 29.17 & d & 7.67 & bcd & 35.33 & $\mathrm{ab}$ & 9.63 & $\mathrm{ab}$ \\
\hline 11 & 156.7 & $\mathrm{ab}$ & 36.27 & bc & 8.70 & $a b$ & 36.37 & $\mathrm{ab}$ & 10.49 & $\mathrm{ab}$ \\
\hline 12 & 240.7 & $a b$ & 43.73 & $\mathrm{a}$ & 9.60 & a & 70.00 & $\mathrm{a}$ & 22.59 & a \\
\hline 13 & 250.0 & $a b$ & 33.93 & bcd & 6.93 & cde & 39.33 & $\mathrm{ab}$ & 11.22 & $a b$ \\
\hline 14 & 298.0 & $\mathrm{a}$ & 28.17 & d & 7.10 & cde & 44.30 & $\mathrm{ab}$ & 13.18 & $\mathrm{ab}$ \\
\hline Mean & 181.1 & & 32.71 & & 7.37 & & 30.50 & & 9.44 & \\
\hline CV (\%) & 31 & & 14 & & 15 & & 48 & & 48 & \\
\hline
\end{tabular}

Values in columns followed by the same letter do not differ significantly at $\alpha=0.05$.

$\mathrm{CV}$ - coefficient of variation 
Total content of coumarins (determined by a spectrophotometric method) in the leaves of the investigated clones ranged from 1.49 to $1.94 \%$. Higher diversity between clones was found in respect of the content of flavonoids and phenolic acids $(0.25-0.55 \%$ and $0.20-0.42 \%$, respectively). Clone no. 10 was distinguished by the high content of all three groups of active compounds (tab. 2).

Table 2 .

Total content of coumarins, flavonoids and phenolic acids in the leaves of southern sweet-grass $(\% \mathrm{DM})$

\begin{tabular}{lcccccc}
\hline Clone No. & \multicolumn{2}{c}{ Coumarins } & \multicolumn{2}{c}{ Flavonoids } & \multicolumn{2}{c}{ Phenolic acids } \\
\hline 1 & 1.81 & ab & 0.32 & cd & 0.29 & bcd \\
\hline 2 & 1.50 & b & 0.26 & d & 0.22 & cd \\
\hline 3 & 1.53 & b & 0.25 & d & 0.20 & d \\
\hline 4 & 1.57 & ab & 0.26 & d & 0.27 & bcd \\
\hline 5 & 1.56 & ab & 0.34 & cd & 0.30 & bcd \\
\hline 6 & 1.67 & ab & 0.34 & cd & 0.35 & ab \\
\hline 7 & 1.49 & b & 0.26 & d & 0.32 & abc \\
\hline 8 & 1.52 & b & 0.55 & a & 0.28 & bcd \\
\hline 9 & 1.50 & b & 0.33 & cd & 0.23 & cd \\
\hline 10 & 1.94 & a & 0.50 & ab & 0.32 & abc \\
\hline 11 & 1.76 & ab & 0.38 & bcd & 0.42 & a \\
\hline 12 & 1.58 & ab & 0.39 & bcd & 0.28 & bcd \\
\hline 14 & 1.51 & b & 0.44 & abc & 0.37 & ab \\
\hline Mean & 1.58 & ab & 0.53 & ab & 0.29 & bcd \\
\hline CV (\%) & 1.61 & & 0.37 & & 0.30 & \\
\hline
\end{tabular}

Values in columns followed by the same letter do not differ significantly at $\alpha=0.05$.

$\mathrm{CV}$ - coefficient of variation

HPLC analyses allowed for the determination of coumarin and relative compounds, namely 3,4-dihydrocoumarin and o-coumaric acid, in the leaves of the clones. Figure 3 shows an exemplary chromatogram of the methanolic extract of the leaves. Coumarin appeared to be a dominant compound in all the investigated plant samples. Its content ranged from 84.00 to $310.85 \mathrm{mg} \cdot 100 \mathrm{~g}^{-1}$ dry matter. Extremely high diversity was found in 3,4-dihydrocoumarin content (17.80-168.45 $\mathrm{mg} \cdot 100 \mathrm{~g}^{-1}$, coefficient of variation $90 \%$ ), and the lowest in o-coumaric acid content (37.50-70.00 mg $\cdot 100 \mathrm{~g}^{-1}$, coefficient of variation $\left.16 \%\right)$. The highest content of both coumarin and 3,4-dihydrocoumarin was characteristic for the clone no. 2 (tab. 3). 
Table 3 .

Content of coumarin and related compounds in the leaves of southern sweet-grass ( $\left.\mathrm{mg} \cdot 100 \mathrm{~g}^{-1} \mathrm{DM}\right)$

\begin{tabular}{lcccccc}
\hline Clone No. & \multicolumn{2}{c}{ Coumarin } & \multicolumn{2}{c}{ 3,4-Dihydrocoumarin } & \multicolumn{2}{c}{ o-Coumaric acid } \\
\hline 1 & 116.20 & d & 39.75 & de & 37.50 & e \\
\hline 2 & 310.85 & a & 168.45 & a & 57.85 & bc \\
\hline 3 & 207.45 & b & 39.05 & de & 43.30 & de \\
\hline 4 & 117.80 & d & 33.50 & def & 46.90 & d \\
\hline 5 & 110.05 & de & 17.80 & g & 45.80 & de \\
\hline 6 & 176.15 & c & 28.45 & efg & 49.70 & c \\
\hline 7 & 117.55 & d & 21.90 & fg & 47.60 & d \\
\hline 8 & 99.25 & de & 30.25 & efg & 48.25 & d \\
\hline 9 & 95.70 & de & 25.50 & efg & 48.90 & c \\
\hline 10 & 84.00 & e & 19.60 & fg & 46.00 & de \\
\hline 11 & 179.01 & bc & 141.05 & b & 70.00 & a \\
\hline 12 & 160.80 & c & 46.90 & d & 50.45 & cd \\
\hline 13 & 108.50 & de & 32.30 & defg & 48.50 & d \\
\hline 14 & 174.50 & c & 71.95 & c & 60.20 & b \\
\hline Mean & 146.99 & & 51.18 & & 50.07 & \\
\hline CV (\%) & 41 & & 90 & & 16 & \\
\hline
\end{tabular}

Values in columns followed by the same letter do not differ significantly at $\alpha=0.05$.

$\mathrm{CV}$ - coefficient of variation

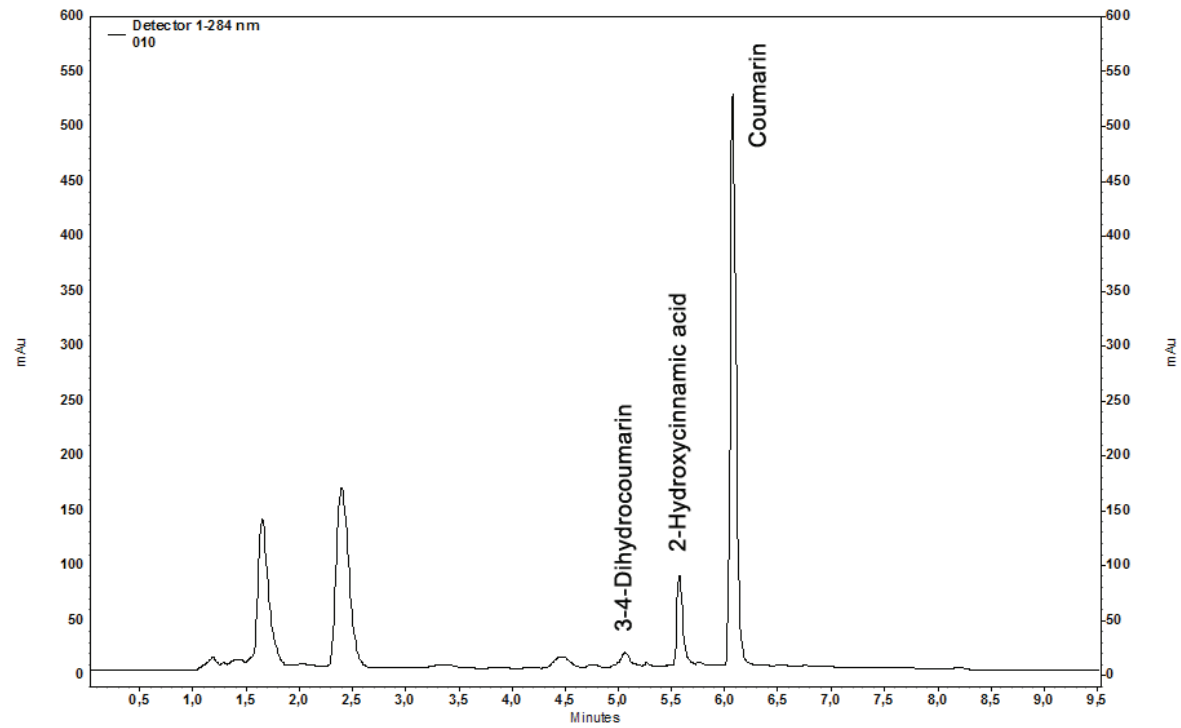

Figure 3.

HPLC-chromatogram of methanolic extract of leaves of southern sweet-grass 


\section{DISCUSSION}

Seeds of southern sweet-grass had been found in the Neolithic settlements in central Poland, which indicated potential collecting practices already at that time [8]. For many years, the herb or leaves of this plant have been intensively harvested as a flavouring raw material for food and cosmetic industry, and - on a smaller scale - for medicinal purposes. Usage of this plant material results mainly from the presence of coumarins (especially coumarin itself). Coumarin is a product of lactonisation of cis-o-hydroxycinnamic acid released from its glucosidic form during drying of leaves. Coumarin has a specific smell and makes the leaves of sweetgrass an important flavoring agent, especially for special brands of alcohols and cigarettes [9].

Intensive harvesting of southern sweet-grass from natural sites is the main threat for the species survival, the more so that the natural sites are scattered and often not rich. The range of occurrence of this species in Poland covers mainly eastern and north-eastern lowland area, where the plant can be found mostly in mixed forest communities [1, 9]. The idea of introduction of Hierochloë species into cultivation arose already in the 70's $[6,10]$. Since then, several agrotechnical experiments have been carried out, indicating the effect of weather conditions, light intensity, fertilization, time of harvest, and drying conditions on the yield of raw material and/or coumarin content [2, 10-13].

Southern sweet-grass is a tuft grass. It can be easily propagated by division. Preliminary studies on in vitro propagation indicate that this method may be also used for the production of plant material for establishing plantations (unpublished data). Vegetative propagation allows to obtain relatively uniform plant material both in respect of morphological traits of plants and accumulation of biologically active compounds or other constituents responsible for non-medicinal usage of some plant organs. Southern sweet-grass is known as an allogamous, wind-pollinated, highly heterozygotic plant. Therefore, it is even more justified to select individuals with desirable traits and use them as a source of clonal material for cultivation. In present study, such clones of selected representatives of one natural population were compared in respect of morphological traits and accumulation of coumarins, flavonoids and phenolic acids in leaves.

Morphological diversity of clones concerned mainly the number of leaves and, in a lesser degree, leaf length and width. Diversity in these parameters resulted in remarkable differences between clones in the weight of leaves per plant. In our previous study [12], high variability in respect of herb yield between individuals originating from two natural populations of southern sweetgrass was observed, too.

The studies concerning coumarin content in southern sweet-grass indicate that this trait is affected by genetic, environmental, and agrotechnical factors. In the study of Węglarz et al. [12], total coumarin content determined by 
spectrophotometric method ranged from 0.22 to $0.60 \%$ in the first year of vegetation, and from 0.30 to $1.50 \%$ in the second year, depending on population and time of harvesting. Wierzchowska-Renke [11] reported that coumarin content in herb of $H$. australis collected at the stage of plant flowering ranged from 0.71 to $2.78 \%$, depending on the age of plants and fertilization (especially with $\mathrm{Mg}$, $\mathrm{Zn}, \mathrm{Mn}, \mathrm{Cu}$, and $\mathrm{Mo}$ ). The clones investigated in the present study appeared to be characterized by relatively high and hardly diversified total coumarin content (1.49-1.94\%). The content of coumarin determined by HPLC method was much lower than the total coumarin content determined spectrophotometrically. Apart from coumarin, which appeared to be a dominant constituent of coumarin fraction, 3,4-dihydrocoumarin (melilotin) and o-coumaric acid were identified. These compounds have been also reported in our previous studies on $\mathrm{H}$. australis $[2,13]$. In the study of Przybył et al. [2] the coumarin content in the leaves of plants representing one population ranged from 87.07 to $1082.43 \mathrm{mg} \cdot 100 \mathrm{~g}^{-1}$ dry matter. In the present study it was less diversified $(84.00-310.85 \mathrm{mg} \cdot 100$ $\left.\mathrm{g}^{-1}\right)$. Melilotin, which is used as a component of perfumes, and o-coumaric acid, which has been reported to reveal antioxidant and anti-obesity activity [14], occurred in much lower amounts.

The data on the content of other phenolic compounds in the raw materials obtained from $H$. australis are scarce. In the study of Podyma et al. [13], two flavonoid compounds (astragalin and rutin) and four phenolic acids (chlorogenic, ellagic, ferulic, and rosmaric acid, beside o-coumaric one) were identified in the leaves of this plant. In the present study the total contents of flavonoids and phenolic acids were determined, but they appeared to be relatively low.

Taking into consideration the yield of raw material and coumarin content, from among the clones compared in the study the most promising and worth regarding in further agrotechnical studies seem to be those numbered 12 and 2.

\section{CONCLUSIONS}

The investigated clones of southern sweet-grass differed distinctly in the number of leaves, their size and weight per plant. Significant differences between the clones concerning accumulation of coumarin and phenolic compounds in these organs were also observed. The differences concerning coumarin content, the compound responsible for the aroma and technological value of leaves, reached over $300 \%$.

\section{ACKNOWLEDGEMENTS}

The studies were supported by the Ministry of Agriculture and Rural Development and the Ministry of Sciences and Higher Education. 


\title{
REFERENCES
}

1. Piękoś-Mirkowa H, Mirek Z. Flora Polski. Atlas roślin chronionych. Warszawa. Multico O.W., 2003:532-533.

2. Przybył JL, Paczesna E, Angielczyk M, Bączek K, Podyma W, Geszprych A, Węglarz Z. Intraspecific variability of southern sweet-grass (Hierochloë australis /Schrad./ Roem. \& Schult.) wild growing in Poland. Acta Hort 2011; 925:89-95.

3. Kohlmünzer S. Farmakognozja. Podręcznik dla studentów farmacji. Warszawa. PZWL, 1998:207.

4. Lake BG. Coumarin metabolism, toxicity and carcinogenicity: relevance for human risk assessment. Food Chem Toxicol 1999; 37(4):423-453.

5. Sproll C, Ruge W, Andlauer C, Godelmann R, Lachenmeier DW. HPLC analysis and safety assessment of coumarin in foods. Food Chem 2008; 109(2):462-469.

6. Wierzchowska-Renke K, Stecka L. Oznaczanie zawartości kumaryn w żubrówce leśnej - Hierochloë australis (Schrad.) Roem. et Schult. Normae Herb 1976; 4:8-16.

7. Farmakopea Polska VI. Warszawa. PTF, 2002.

8. Bieniek A. Archaeobotanical analysis of some early Neolithic settlements in the Kujawy region, central Poland, with potential plant gathering activities emphasised. Veget Hist Archaeobot 2002; 11(1-2):33-40.

9. Gawłowska J, Sulma T, Wierzchowska-Renke K. Turówka wonna Hierochloë odorata i turówka leśna Hierochloë australis - zasoby i zagrożenia. Chrońmy Przyrodę Ojczystą 1989; 5-6:60-69.

10. Wierzchowska-Renke K, Sulma T. Badanie ziela turówki (żubrówki) Herba Hierochloë. II. Zawartość kumaryny w zielu turówki wonnej - Hierochloë odorata Wahlb. i turówki leśnej - Hierochloë australis Roem et Schult. w okresie wegetacji. Acta Polon Pharm 1973; 30(3):317-323.

11. Wierzchowska-Renke K. Wpływ nawożenia wybranymi pierwiastkami na sezonową zawartość kumaryny oraz niektórych makro- i mikroelementów w zielu Hierochloë australis. Ann Acad Med Gedan 1993; 23:27-35.

12. Węglarz Z, Geszprych A, Angielczyk M, Pawełczak A. Wstępne badania nad plonowaniem i wewnątrzgatunkową zmiennością chemiczną turówki leśnej (Hierochloë australis /Schrad./ Roem. \& Schult.). Zesz Probl Post Nauk Roln 2004; 497:621-626.

13. Podyma W, Bączek K, Angielczyk M, Przybył JL, Węglarz Z. The influence of shading on the yield and quality of southern sweet-grass (Hierochloë australis (Schrad.) Roem. \& Schult.) raw material. Herba Pol 2010; 56(4):14-19.

14. Hsu CL, Wu CH, Huang SL, Yen GC. Phenolic compounds rutin and o-coumaric acid ameliorate obesity induced by high-fat diet in rats. J Agric Food Chem 2009; 57(2):425-431.

CECHY UŻYTKOWE WYBRANYCH KLONÓW TURÓWKI LEŚNEJ (HIEROCHLOË AUSTRALIS /SCHRAD./ ROEM. \& SCHULT.)

\author{
KATARZYNA BACZZEK *, MIROSŁAW ANGIELCZYK, JAROSŁAW L. PRZYBYŁ, MARCIN \\ EJDYS, ANNA GESZPRYCH, ZENON WĘGLARZ
}

Laboratorium Nowych Technologii Wytwarzania Produktów Zielarskich

i Oceny ich Jakości

Katedra Roślin Warzywnych i Leczniczych

Szkoła Główna Gospodarstwa Wiejskiego w Warszawie 
ul. Nowoursynowska 166

02-787 Warszawa, Polska

*autor, do którego należy kierować korespondencję: katarzyna_baczek@sggw.pl, tel.: +482259322 58, faks: +48225932232

Streszczenie

Turówka leśna (Hierochloë australis /Schrad./ Roem. \& Schult., Poaceae), potocznie nazywana żubrówką, jest wieloletnią trawą kępkową występującą rzadko na stanowiskach naturalnych w Europie Północnej i Wschodniej. Rośnie ona na brzegach lasów liściastych i mieszanych. Surowcem pozyskiwanym z tej rośliny (wyłącznie ze stanowisk naturalnych) są liście bogate w związki kumarynowe, a w szczególności w kumarynę, odpowiedzialną za specyficzny słodkawy aromat liści. W Polsce surowiec ten wykorzystywany jest głównie do aromatyzowania napoi alkoholowych. W ostatnich latach obserwuje się rosnący popyt na ten surowiec, co skutkuje niekontrolowanym i nadmiernym jego pozyskiwaniem. Jednym z najbardziej skutecznych sposobów zapobieżenia temu zagrożeniu wydaje się być wprowadzenie turówki leśnej do uprawy. Jest to roślina obcopylna i heterozygotyczna, u której obserwuje się wyraźne zróżnicowanie wewnątrzgatunkowe. W niniejszej pracy przeprowadzono charakterystykę morfologiczną i chemiczną czternastu klonów tej rośliny uzyskanych z wybranych pojedynków z populacji turówki leśnej rosnącej we Wschodniej Polsce. Badane klony różniły się istotnie masą liści (od 3,76 to 22,59 g suchej masy na roślinę). Ogólna zawartość kumaryn w tym surowcu wahała się od 1,49 do 1,94\%, flawonidów - od 0,25 do 0,55\% i kwasów fenolowych - od 0,20 do 0,42\%. Trzy związki kumarynowe zostały zidentyfikowane w liściach badanych klonów przy użyciu HPLC, tj. kumaryna, 3,4-dihydrokumaryna i kwas o-kumarowy. Zawartość kumaryny wahała się od 84,00 do 310,85, 3,4-dihydrokumaryny: od 17,80 do 168,45 , a kwasu o-kumarowego: od 37,50 do $70,00 \mathrm{mg} \cdot 100 \mathrm{~g}^{-1}$ suchej masy.

Słowa kluczowe: zmienność roślin, cechy morfologiczne, kumaryny, flawonoidy, fenolokwasy 